\title{
EXPERIMENTAL ARRANGEMENTS FOR INVESTIGATION OF SOIL STRESSES DEVELOPED AROUND A DISPLACEMENT PILE ${ }^{\mathrm{i})}$ THE USE OF MINIATURE SOIL STRESS MEASURING CELLS IN LABORATORY APPLICATIONS INVOLVING STRESS REVERSALS ${ }^{\text {ii) }}$
}

\author{
Closure by RICHARD J. JARDINE ${ }^{\text {iii) }}$
}

The authors thank the writer for his interest in our papers and note his alternative Null Soil Pressure Gage (NSPG) design. The latter operates without the sensing diaphragm membrane deflecting, as a regulated air pressure supply is fed into the housing to counterbalance the changing soil pressures. We also note that a cell $42 \mathrm{~mm}$ in diameter has been used successfully to record static or pseudo-static structural boundary stress up to several hundred $\mathrm{kPa}$ (Talesnick, 2005) and that adaption for measurements in-soil requires a device with an $80 \mathrm{~mm}$ diameter face that is still under development.

Interestingly, we were already aware that somewhat smaller sized null-pressure devices had been used successfully in the 1980s at the University of Oxford for field pile research (see for example Coop, 1987). However, noting our experimental requirements for dozens of much smaller sensors to be deployed around a $36 \mathrm{~mm}$ diameter pile, and our need to capture the extreme stresses (up to several MPa) developed during pile driving and long-term set-up, we had to conclude that the null-pressure principle did not offer a viable or practical alternative for our work. The main reasons are listed below:

(1) The pneumatic devices need a longer response time than the mechanical gauges we deployed. We note that the writer reported a response time for the structural boundary NSPG of slightly less than 1 second for $10 \mathrm{kPa}$ pressure change (Talesnick, 2005) and a longer time for a larger in-soil device. We suspect that it may be impossible to capture the large transient stresses (with changes of MPa over a few seconds) de-

i) Vol. 49, No. 5, October 2009, pp. 661-673 (Previous discussion by Mark Talesnick Vol. 50, No. 3 June 2010, 447-448)

i) Vol. 49, No. 5, October 2009, pp. 675-688 (Previous discussion by Mark Talesnick Vol. 50, No. 3 June 2010, 447-448).

iii) Proffesor, Imperial College London, Department of Civil and Environmental Engineering, South Kensington Campus, Lonon (r.jardine@ imperial.ac.uk). 
veloped as our pile tip approached the instrument positions of greatest interest;

(2) The size of the writer's in-soil device is more than double the diameter of the mini IC pile, potentially introducing strong interaction with the pile and perturbation of the actual field stresses. Our desired near field measurements would be impossible with such a device;

(3) The null-pressure devices require not only electrical cables, but also air pressure feed lines, which lead to an undesirably heavily reinforced and congested sand mass in our tests. Even when equipped with the finest practical electrical wires, ground reinforcement action is developed by the 40 cells' cables (Jardine et al., 2009);

(4) It would not be practical to secure a fully undisrupted supply of air pressure to enable stress monitoring for up to 6 months, as in our testing. The supporting air pressure supply system required for forty or more sensors would be highly cumbersome and expensive;

(5) To our knowledge, the writer's NSPG has yet to be commercialized and the overall expense is therefore unknown. As with all university research, cost is also an important consideration. However, the TML and Kyowa cells used in our research are widely available and have been employed in earlier related laboratory research (e.g., Foray et al., 1993).

The writer also questions why no in-soil calibration was conducted for the Surface Stress Transducers (SSTs) on the mini ICP. Arching makes calibrations with curved instruments inherently very difficult to undertake reliably. But the main reason that calibrations were not required is that the SSTs are inherently much stiffer, much less prone to cell action and can be checked independently during use. We proved that cell action was not significant with our original ICP designs by comparing independent local and average shaft shear stress measurements. Jardine (1985), Bond (1989) and Bond et al. (1991) gave full details of the analysis and verification procedures; these same features carry over to the current mini ICP de- sign.

Finally, it should be stressed that the main purpose of the Zhu et al. paper was to show the steps that we had to take to obtain credible measurements in our highly nonlinear and hysteretic problem. We were also keen to warn researchers of the potential errors with the popular diaphragm cells for applications of the type we describe, noting that their use has been quoted by many authors. Our advice is to adopt capacities far above the level of the expected measurements, even at the risk of losing resolution, and then to calibrate very carefully. We hope that readers find this advice useful and we look forward to better sensors being available, while noting that these must however have appropriate sizes, cabling configurations, system requirements and cost.

We acknowledge that null pressure devices may offer advantages and better measurements in some cases, but note that these could not be realized in the application we describe.

\section{References}

6) Bond, A. J. (1989): Behaviour of displacement piles in overconsolidated clays, Ph.D. Thesis, University of London.

7) Bond, A. J., Jardine, R. J. and Dalton, J. C. P. (1991): The design and performance of the Imperial College instrumented pile, ASTM, Geotechnical Testing Journal, 14(4), 413-424.

8) Coop, M. R. (1987): The axial capacity of driven piles in clay, DPhil Thesis, University of Oxford.

9) Foray, P., Colliat, J-L. and Nauroy, J. F. (1993): Bearing capacity of driven model piles in dense sands from calibration chamber tests, Proc., 25th Offshore Technology Conference, Houston, Texas, OTC paper 7194, 2, 655-665.

10) Jardine, R. J. (1985): Investigations of pile-soil behavior, with special reference to the foundations of offshore structures, Ph.D. Thesis, University of London (Imperial College).

11) Jardine, R. J., Zhu, B. T., Foray, P. and Yang, Z. X. (2009): Measurement of stress field developed around close-ended piles in sand, Under review by Geotechnique.

12) Talesnick, M. (2005): Measuring soil contact pressure on a solid boundary and quantifying soil arching, ASTM Geotechnical Testing Journal, 28(2), 171-179. 